\section{ECONOMICS}

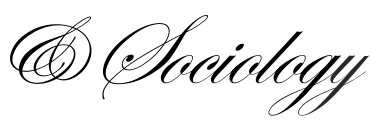

\title{
LABOUR MIGRATION TRENDS IN THE SLOVAK REPUBLIC
}

\begin{abstract}
The authors of the study draw attention to the factors making the workforce leave the Slovak labour market to work abroad. Survey respondents worked abroad. There is no institution in the Slovak Republic keeping records about the number of Slovaks who study and work abroad. There are only estimates available based on secondary information, such as registration of citizens with health insurance companies. In the future, labour shortages will become a serious problem not only for developed EU countries, but also for the Slovak Republic. Therefore, it is necessary to analyse the reasons why, especially young people, decide to leave Slovakia to work abroad.

The purpose of the study is to analyse selected areas of issues arising from the questionnaire survey conducted by the Department of Management and Human Resource Development of the Faculty of Social and Economic Relations from November 2015 to January 2016. 658 respondents participated in the survey, and the questionnaire contained 34 questions with 6 attributive descriptions. The findings related to the selected areas of issues are presented in the study.
\end{abstract}

DOI: $10.14254 / 2071-$

789X.2016/9-2/11

JEL Classification: F15, F22, J61, O15, R23

Keywords: migration, labour migration, migration process, international migration, workforce.

\section{Introduction}

The origins of scientific research which can be traced back to the second half of the $19^{\text {th }}$ century mark the beginning of exploring other sciences, both social and economic ones. In this period of time, empirical science research was developed, such as ethnography, geography, political science and many others that laid foundations for the exploration of a number of theories of international human migration and made them interdisciplinary in character. In 1885, E. G. Ravenstein published a paper entitled "The Laws of Migration". Having utilized statistical data on British migration, he inferred the laws of migration, such as for instance distance, types of migrants, gender-specific motives for migration, etc. (Ravenstein, 1885; Gress, 2014).

Ageing population, in particular in the EU countries made the investigation of labour migration, as well as its causes and effects for individual labour markets of primary concern (Čajka et al., 2014). There are various reasons for labour migration. Generally, there are two reasons for international migration, i.e. economic and non-economic ones. Economic reasons include differences between wages, searching for farmland and striving to acquire new skills 
in the labour market. Non-economic reasons include political, religious, racial or ethnic motives (Muchová et al., 2011, p. 102; Kumpikaite, Zickute, 2012).

Approaches of countries to migration (Czaika, de Haas, 2013; Sadova, 2010) will depend on whether or not there is a need for migrants in a given country. Presently, the need is mainly associated with maintaining economic performance of the country and the demand for workforce from either quantitative or qualitative perspective.

Effective management of migration processes has become a political priority in most countries. There has been an overwhelming consensus on migration - if managed effectively, it can be greatly beneficial to countries of both origin and destination (Lipková et al., 2011, p. 331; Bilan, 2014; Streimikiene et al., 2016).

Migration is a relatively complex concept which refers to several different types of human movements, such as for instance change of residence, labour migration, seasonal migration, circular migration, etc. The most common categorization takes into account geographical aspect of human mobility, and thus international migration, internal migration and cross-border migration are distinguished. The International Organization for Migration (IOM) defines international migration as "the movement of a person or a group of persons from one geographical unit to another across an administrative or political border, for temporary or permanent settlement, in a place other than their place of origin" (IOM, 2003; Divinský, 2009; Vojtovič, 2013; Thomas, 2016).

Therefore, the term international migration will be used throughout the paper. In the paper, motivating factors of Slovak citizens to move abroad for employment purposes were examined. The issue of the migration of Slovak workers to other EU countries seems to be a problem for the Slovak economy. That is why the Slovak government are preparing measures to tackle it. Apparently, there are no exact and real data on the number of labour migrants, so the extent and seriousness of the problem cannot be judged objectively. Surveys conducted on migration of Slovak citizens for employment purposes abroad provide only a vague picture of the development of the problematic issue. There are several reasons why there is a lack of clear and unambiguous data: plurality of migration channels (through which Slovak citizens seek and find employment abroad - EURES, agencies offering jobs abroad, temporary employment agencies, individual job search etc.), variety and incompatibility of methodological approaches (immigration cards, personal identification numbers, residence permits, work permits - changing jobs often requires a new registration in the register of immigrant workers, when quitting jobs, leaving the labour market or country, there is no need to get "unregistered"), periodicity of statistical data and their nature (terms of processing and publishing data on migrant workers differ across the EU).

\section{Purpose and methods}

Labour migration has obvious disadvantages for the economy of the Slovak Republic. There are emerging shortages of skilled labour in some sectors, occupations and regions (Cuhlová, 2015). A high number of young people, leaving Slovakia in order to work abroad which are thus withdrawn from the Slovak workforce is a serious problem for the Slovak labour market. Despite this fact, there is no institution keeping records of the total number of Slovak citizens working or living abroad.

The main purpose of the study is to find and clarify the motivating factors of Slovak citizens to move abroad for employment purposes.

The questionnaire method was used to obtain the relevant data. The questionnaire contained 34 questions and 6 attributive descriptions. The questionnaire was randomly distributed in the months of November 2015 - January 2016 among 658 respondents who had international work experience. The target group were Slovak citizens having personal 
experience with labour migration to any foreign country. The sample of respondents is considered to be sufficient, given that there are no recorded data in the Slovak Republic about the number of Slovak citizens working abroad.

The questionnaire contained closed and semi-closed ended questions in which the respondents could provide particular and textual responses. The study presents some survey findings.

To process the data, the statistical parametric method - chi-square test was employed to establish provable relationships between two attributes. Attributes can be qualitative, quantitative discrete, and continuous quantitative combined into groups. The data are shown in a contingency table and frequencies greater than 10 are highlighted. Chi-square test is commonly used to compare observed and expected frequencies. If there were values less than 0.05 , the assumption was rejected.

To test the assumptions, Cramer's V test was used to determine the strengths of associations. This coefficient takes values from $<0.1>$.

\section{Research findings}

Out of 658 respondents who participated in the survey were 329 males (50\%), 317 females $(48.2 \%)$, and 12 respondents $(1.8 \%)$ did not mark their sex on the survey. Table 1 shows respondents by age, the majority of respondents were aged $21-25$ years $(39.2 \%)$ and $26-35$ years $(32.2 \%)$, and the least proportion of respondents were above 56 years $(2 \%)$.

Table 1. Respondents by age

\begin{tabular}{lc}
\hline up to 20 years of age & 29 \\
\hline aged between $21-25$ years & 258 \\
\hline aged between $26-35$ years & 212 \\
\hline aged between $36-45$ years & 85 \\
\hline aged between $46-55$ years & 49 \\
\hline above 56 years & 13 \\
\hline no answer & 12 \\
\hline
\end{tabular}

Source: own results.

The data on educational attainment show that the majority of respondents completed secondary education with school-leaving examination (316 respondents, $48 \%$ ), and the least number of respondents (45 respondents, i.e. 6.8\%) competed Grammar School studies.

Table 2. Respondents by educational attainment

\begin{tabular}{lc}
\hline Secondary professional school certificate of apprenticeship & 110 \\
\hline Complete secondary with school leaving examinations & 316 \\
\hline Grammar School & 45 \\
\hline University education & 176 \\
\hline Not specified & 11 \\
\hline
\end{tabular}

Source: own results.

The survey was to find whether there is a correlation between the positions filled abroad and previously held positions in Slovakia, or command of foreign language and the 
country of destination, or other factors, such as mainly wages, working conditions, etc. That is why, the first research question was formulated as follows: Is there a correlation between the selected job abroad and the position previously held in Slovakia? The question was answered by 585 respondents. Responses are listed in Tables 3 and 4.

Table 3. Contingency table. Research question: "Was the job abroad selected according to the position previously held in Slovakia?“‘

\begin{tabular}{|c|c|c|c|c|c|c|c|}
\hline \multirow{2}{*}{$\begin{array}{l}\text { What was your job } \\
\text { title in Slovakia? (if } \\
\text { you held numerous } \\
\text { positions, indicate } \\
\text { the most recent) }\end{array}$} & \multirow[b]{2}{*}{$\begin{array}{l}\text { Worker, } \\
\text { cook, } \\
\text { waiter, } \\
\text { etc. }\end{array}$} & \multicolumn{6}{|c|}{ What was / is your job title abroad? } \\
\hline & & $\begin{array}{c}\text { Cleri- } \\
\text { cal } \\
\text { staff }\end{array}$ & $\begin{array}{c}\text { Care } \\
\text { worker, } \\
\text { baby-sitter, } \\
\text { nurse, etc. }\end{array}$ & $\begin{array}{l}\text { Skilled } \\
\text { worker }\end{array}$ & $\begin{array}{l}\text { Manage- } \\
\text { rial staff }\end{array}$ & Other & Total \\
\hline $\begin{array}{l}\text { Worker or } \\
\text { employee at the } \\
\text { lowest level in an } \\
\text { organization }\end{array}$ & 203 & 3 & 18 & 12 & 9 & 20 & 265 \\
\hline Clerical staff & 34 & 20 & 19 & 1 & 3 & 12 & 89 \\
\hline Skilled worker & 25 & 1 & 10 & 17 & 2 & 3 & 58 \\
\hline Managerial staff & 11 & 2 & 2 & 4 & 11 & 3 & 33 \\
\hline Other & 70 & 5 & 17 & 1 & 9 & 38 & 140 \\
\hline All categories & 343 & 31 & 66 & 35 & 34 & 76 & 585 \\
\hline
\end{tabular}

Source: own results.

Table 4. The type of job done abroad is not conditioned by the position held previously at home

\begin{tabular}{lccr}
\hline \multirow{2}{*}{ Statist. } & \multicolumn{3}{c}{ Statist.: What was / is your job title abroad? } \\
& \multicolumn{2}{c}{ What was your job title in Slovakia? } \\
\cline { 2 - 4 } & Chi-square & sv & $\mathrm{P}$ \\
\hline Pearson Chi-square & 248,3450 & $\mathrm{df}=20$ & $\mathrm{p}=0,0000$ \\
\hline M-V Chi-square & 184,7548 & $\mathrm{df}=20$ & $\mathrm{p}=0,0000$ \\
\hline Fi &, 6515530 & & \\
\hline Contingency coefficient &, 5459027 & & \\
\hline Cramer's V &, 3257765 & & \\
\hline Coefficient of uncertainty & $\mathrm{X}=, 1201874$ & $\mathrm{Y}=, 1145332$ & $\mathrm{X} / \mathrm{Y}=, 11729$ \\
\hline
\end{tabular}

Source: own results.

Conclusion: The assumption was rejected at the significance level $\alpha=0.05(\mathrm{p}<0,05)$

The assumption was rejected at the significance level $\alpha=0.05(\mathrm{p}<0,05)$ for Pearson chi-square statistics. There exists statistically significant dependence between the variables observed (The type of job done abroad is conditioned by the position held previously at home). Cramer's V value amounts to 0.3257765, meaning moderate to substantial dependence.

Hence, it can be inferred that the type of employment abroad searched for by applicants is conditioned by the position held previously in Slovakia. Respondents have the skills and experience for doing their particular jobs abroad, thus using their previous experience and skills, and not switching to new jobs in different industries. In addition, it has 
to be taken into account that changing careers often necessitates not only putting in a great deal of effort, but also expending money, for instance for retraining.

Next, the correlation between the return migration intentions and age of respondents were examined. The following research question was formulated: Does the intention to go back to their home country depend on the age of respondents? When processing the data, we worked with 546 questionnaires as 112 respondents did not answer this question. The results are shown in Tables 5 and 6.

Table 5. Contingency table. Research question: "Does the intention to go back to their home country depend on age of respondents?"

\begin{tabular}{lrrr}
\hline \multirow{2}{*}{ Age } & \multicolumn{3}{c}{$\begin{array}{c}\text { When working abroad is no longer attractive for you, } \\
\text { would you like to go back to Slovakia? }\end{array}$} \\
\cline { 2 - 5 } & Yes & No & Total \\
\hline Up to 20 years of age & $\mathbf{2 3}$ & 8 & 31 \\
\hline Aged between 21 to 25 yrs. & $\mathbf{1 7 3}$ & $\mathbf{4 3}$ & 216 \\
\hline Aged between 26 to 35 yrs. & $\mathbf{1 3 7}$ & $\mathbf{3 9}$ & 176 \\
\hline Aged between 36 to 45 yrs. & $\mathbf{5 3}$ & $\mathbf{1 7}$ & 70 \\
\hline Aged between 46 to 55 yrs. & $\mathbf{3 5}$ & 8 & 43 \\
\hline Above 56 yrs. & $\mathbf{9}$ & 1 & 10 \\
\hline All categories & 430 & 116 & 546 \\
\hline
\end{tabular}

Source: own results.

The assumption_was tested at the significance level $\alpha=0.05$

Table 6. The decision on returning to Slovakia does not depend on the age of respondents

\begin{tabular}{lccc}
\hline \multirow{2}{*}{ Statist. } & \multicolumn{4}{c}{$\begin{array}{l}\text { Statist.: When working abroad is no longer attractive for } \\
\text { you, would you like to go back to Slovakia? }\end{array}$} \\
\cline { 2 - 4 } & Chi-square & $\mathrm{sV}$ & $\mathrm{p}$ \\
\hline Pearson Chi-square & 2,026099 & $\mathrm{df}=5$ & $\mathrm{p}=, 84552$ \\
\hline $\mathrm{M}-\mathrm{V}$ Chi-square & 2,143777 & $\mathrm{df}=5$ & $\mathrm{p}=, 82891$ \\
\hline Fi &, 0609164 & & \\
\hline Contingency coefficient &, 0608037 & & \\
\hline Cramer's V &, 0609164 & & $\mathrm{X} / \mathrm{Y}=, 00201$ \\
\hline Coefficient of uncertainty & $\mathrm{X}=, 0013715$ & $\mathrm{Y}=, 0037958$ & \\
\hline
\end{tabular}

Source: own results.

The assumption was not rejected, i.e. there is no statistically significant dependence between the decision to return to Slovakia and age of respondents at the significance level 0.05 .

There has been done a lot of research attempting to establish the so-called migration profiles. In 2004 (Slovakia's accession into the EU), the percentage of migrants aged 15 to 24 years was nearly 30 per cent, and along with 25 to 34 year-olds, they made up approximately two thirds of all migrants. Until 2012, the percentage of 15 to 24 year-olds dropped to approximately 10 per cent and the percentage of 15 to 34 year-olds dropped to 48 per cent (profesia.pravda.sk). 
In the survey, the majority of respondents $(82 \%)$ between 21 to 25 years of age intend to go back to Slovakia, whereas respondents up to 20 years of age do not plan to return to Slovakia (25.6\%). Detailed results are listed in Table 7.

Table 7. When working abroad is no longer attractive for you, would you like to go back to Slovakia?

When working abroad is no longer attractive for you, would you like to go back to Slovakia?

\begin{tabular}{lccc}
\hline & Yes & No & Did not answer \\
\hline Up to 20 years of age & $74.2 \%$ & $25.6 \%$ & $0.2 \%$ \\
\hline Aged between 21 to 25 yrs. & $82 \%$ & $16.7 \%$ & $1.3 \%$ \\
\hline Aged between 26 to 35 yrs. & $64.9 \%$ & $18.5 \%$ & $16.6 \%$ \\
\hline Aged between 36 to 45 yrs. & $63.1 \%$ & $20.2 \%$ & $16.7 \%$ \\
\hline Aged between 46 to 55 yrs. & $72.9 \%$ & $16.6 \%$ & $10.5 \%$ \\
\hline Above 56 yrs. & $69.2 \%$ & $7.7 \%$ & $23.1 \%$ \\
\hline
\end{tabular}

Source: own results.

The difference between neoclassical theory and new theory is that the former assumes permanent relocation of migrants to maximize their lifetime earnings, whereas the latter is based on the assumption of migrants' temporary relocation abroad in order to overcome domestic market irregularities.

The Strategy of the Slovak Republic for youth for the years 2014-2020 developed by the Ministry of Education says that more than $70 \%$ of young people in Slovakia would prefer to live in another country. Since young people under 30 years of age represent an essential part of the Slovak Republic's population (37.4\%), it is important that they remain in the Slovak labour market. The survey, however, did not confirm this trend, since the majority of respondents intend to return to Slovakia. It is debatable whether they will come back to Slovakia or will live abroad permanently. Their decisions will be affected by not only economic but also political factors.

The next research question was as follows: Is there a correlation between the anticipated length of employment abroad and the sex of respondents?

620 questionnaires were worked with since 38 respondents did not answer this question.

Table 8. Contingency table. Research question: Is there a correlation between the anticipated length of employment abroad and the sex of respondents?

\begin{tabular}{lcccccccc}
\hline & \multicolumn{8}{c}{ How long do you plan to work abroad? } \\
\cline { 2 - 10 } Sex & $\begin{array}{c}\text { Up to } \\
\text { 1 year }\end{array}$ & $\begin{array}{c}1-3 \\
\text { years }\end{array}$ & $\begin{array}{c}3-5 \\
\text { years }\end{array}$ & $\begin{array}{c}5-10 \\
\text { years }\end{array}$ & $\begin{array}{c}\text { Above } \\
\text { 10 years }\end{array}$ & $\begin{array}{c}\text { Perma- } \\
\text { nently }\end{array}$ & $\begin{array}{c}\text { I no longer work abroad, } \\
\text { and I do not intend to } \\
\text { work abroad }\end{array}$ & Total \\
\hline Male & $\mathbf{7 4}$ & $\mathbf{4 1}$ & $\mathbf{4 2}$ & $\mathbf{4 3}$ & $\mathbf{2 3}$ & $\mathbf{5 4}$ & $\mathbf{4 5}$ & 322 \\
\hline Female & $\mathbf{5 7}$ & $\mathbf{4 4}$ & $\mathbf{5 0}$ & $\mathbf{3 0}$ & $\mathbf{2 7}$ & $\mathbf{4 4}$ & $\mathbf{4 6}$ & 298 \\
\hline Total & 131 & 85 & 92 & 73 & 50 & 98 & 91 & 620 \\
\hline
\end{tabular}

Source: own results. 
Table 9. The anticipated length of employment abroad does not depend on the sex of respondents

\begin{tabular}{lccc}
\hline \multirow{2}{*}{ Statist. } & \multicolumn{3}{c}{ Statist.: How long do you plan to work abroad? } \\
\cline { 2 - 4 } & Chi-square & $\mathrm{sv}$ & $\mathrm{p}$ \\
\hline Pearson Chi-square & 5,753696 & $\mathrm{df}=6$ & $\mathrm{p}=, 84552$ \\
\hline M-V Chi-square & 5,766493 & $\mathrm{df}=6$ & $\mathrm{p}=, 82891$ \\
\hline Fi &, 0963336 & & \\
\hline Contingency coefficient &, 0958897 & & \\
\hline Cramer's V &, 0963336 & & $\mathrm{X} / \mathrm{Y}=, 00357$ \\
\hline Coefficient of uncertainty & $\mathrm{X}=, 0024320$ & $\mathrm{Y}=, 0067164$ & \\
\hline
\end{tabular}

Source: own results.

The assumption was not rejected, i.e. there exists statistically significant dependence between the decision to return to Slovakia and age of respondents at the significance level 0.05 .

It can be inferred that the length of employment abroad does not depend on the sex of respondents. It was found that $23 \%$ of men and $19 \%$ of women want to work abroad for one year. $16.8 \%$ men and $14.8 \%$ women plan to work abroad permanently. It follows that respondents seek for temporary work, gaining experience or improving their foreign language skills.

In addition, it was attempted to find whether a command of foreign languages influences the choice of the country. The next research question was formulated as follows: Is there a correlation between a command of foreign languages and the selection of destination countries?

Table 10. Contingency table. Research question: Is there a correlation between the command of foreign languages and selection of destination countries?

\begin{tabular}{|c|c|c|c|c|c|c|c|c|}
\hline $\begin{array}{l}\text { Multiple } \\
\text { response }\end{array}$ & & ow did you & lecide $\mathrm{v}$ & ich country & $s$ best fo & to fin & mployment? & \\
\hline $\begin{array}{l}\text { Lan- } \\
\text { guage } \\
\text { skills }\end{array}$ & $\begin{array}{l}\text { Lan- } \\
\text { guage } \\
\text { skills }\end{array}$ & $\begin{array}{l}\text { Distance } \\
\text { and } \\
\text { transport } \\
\text { connec- } \\
\text { tion }\end{array}$ & Other & $\begin{array}{l}\text { Climate } \\
\text { and } \\
\text { geograph } \\
\text { ic condi- } \\
\text { tions }\end{array}$ & $\begin{array}{l}\text { Wage } \\
\text { and } \\
\text { welfare } \\
\text { benefit } \\
\text { levels }\end{array}$ & $\begin{array}{c}\text { Work } \\
\text { condi- } \\
\text { tions }\end{array}$ & $\begin{array}{l}\text { Culture, } \\
\text { mentality } \\
\text { and trade- } \\
\text { tions of a } \\
\text { nation }\end{array}$ & $\begin{array}{l}\text { Row } \\
\text { Sums }\end{array}$ \\
\hline English & 187 & 43 & 47 & 26 & 124 & 96 & 1 & 524 \\
\hline German & 119 & 37 & 23 & 10 & 90 & 64 & 1 & 344 \\
\hline Other & 14 & 8 & 4 & 5 & 8 & 13 & 1 & 53 \\
\hline Russian & 38 & 12 & 12 & 4 & 26 & 34 & 1 & 127 \\
\hline French & 10 & 1 & 4 & 0 & 4 & 4 & 0 & 23 \\
\hline $\begin{array}{l}\text { All } \\
\text { categories }\end{array}$ & 368 & 101 & 90 & 45 & 252 & 211 & 4 & 1071 \\
\hline
\end{tabular}

Source: own results.

Respondents could provide multiple answers, therefore the chi-square test of association of variables with multiple responses was done. 
Multiple marginal idependence test (MMI)

$\chi_{M M I}^{2}=81.66$

$\chi_{0,95}^{2}(35)=48.801805$

$\chi_{M M I}^{2}>\chi_{0,95}^{2}(35)$, thus the assumption was rejected.

In the past decade, English language has become the second language spoken by young people. After the EU accession, they started enjoying the benefits of European integration: they can travel, earn and study freely abroad.

It was found that respondents search for a job in a country whose language they can speak. In routine performance of some jobs, such as for example those of care workers, it is a necessity to speak the language of the host country. Foreign language skills make job hunting, establishing social relationships and friendships, as well as integrating of migrants much easier.

The following control question was made: "Which criteria did you find important when deciding which country is best for you to find employment?" To answer the question, one respondent could select multiple answers. $28.5 \%$ respondents selected the destination country based on their language(s) spoken, whereas higher wages and welfare benefits were the major determinants for $26.7 \%$ of respondents.

Table 11. How did you decide which country is best for you to find employment?

\begin{tabular}{lc}
\hline Language skills & $28.50 \%$ \\
\hline Distance and transport connection & $6.60 \%$ \\
\hline Climate and geographic conditions & $3.60 \%$ \\
\hline Wage and welfare benefit levels & $26.70 \%$ \\
\hline Culture, mentality and traditions of a nation & $6.90 \%$ \\
\hline Work conditions & $20.10 \%$ \\
\hline Other & $7.30 \%$ \\
\hline Did not answer & $0.30 \%$ \\
\hline
\end{tabular}

Source: own results.

\section{Conclusion}

In the paper, factors motivating Slovak citizens to move abroad for employment purposes were found and analysed. The factors that play an important role in choosing a country of destination mainly include language skills, wage levels, social benefits in the country of destination as well as the conditions of work. Today, the decision of leaving Slovakia to work abroad is influenced not only by economic factors, but also political situation in the world and Europe, in particular.

Freedom of movement for persons in the European Union is one of the cornerstones of the European citizenship, yet there are some countries that are concerned about the existing rules. People leaving their own countries and moving to new ones are mostly seeking to live peaceful and fulfilling lives, which they could not have led in their home countries.

Migration is a phenomenon affecting economies of countries of both origin and destination. Moreover, it has a huge impact on the social structure of the population, political preferences, etc. Movement of population from country to country does not only have 
economic consequences. There are also other aspects included, such as historical, demographic, geographic and other aspects. As for the Slovak Republic, people mostly migrate for economic reasons, and this is particularly true for those having the lowest earning occupations compared to higher-paying identical jobs in destination countries, thus the standard of living of foreign migrants and their families can be considerably improved.

There are no official and accurate data about the number of Slovaks who work abroad available since there is no institution in the Slovak Republic keeping such records. Slovak citizens are obliged to pay their health insurance, so the approximate data about Slovaks working abroad could be obtained from the health insurance company data. There are, however, some Slovak citizens registered with the Labour Offices who perform undeclared work abroad. Therefore, these data may be inaccurate as well as the fact that Slovak citizens sometimes pay their health insurance in another country.

Slovak citizens mostly work in the Czech Republic, which is currently having shortage of labour and 100,000 vacancies are available in the Czech labour market. The main reasons for commuting or relocating to the Czech Republic for employment purposes are the chances of getting desired jobs, slight cultural differences and practically no language barrier between the both countries. Since both countries share similar cultural values, the workforce can get rapidly integrated not only in the labour market but also in society. The Czech Republic is followed by the United Kingdom, Germany and Austria. These choices, however, are conditioned by the foreign language proficiency of labour migrants.

Another grave problem faced by the Slovak Republic is the migration of young population abroad for study purposes, mainly to study at Czech universities. This way, the countries of destination can educate and integrate the future workforce into their labour markets. It can hardly be expected that young people will return home after studying abroad for five or more years, having established their social contacts or having completed work placements abroad, etc.

Although not a recent phenomenon, there have never been such favourable conditions for migration as in the today's era of globalization. Rich countries lacking in a skilled labour force are developing measures for attracting highly-skilled foreign labour. Regarding lowskilled labour, they are much more cautious although this might not be quite true in the context of the migration crisis. Third country migrants represent low-skilled workers whose integration in host countries in Europe is not easy. The Slovak Republic does not tackle the issue of brain drain and the accompanying problems in a systematic manner. Moreover, the Slovak labour market begins to lack skilled workforce, therefore careful attention should be paid to these issues.

\section{Acknowledgement}

The paper was elaborated under the project 1/0736/14 titled Trends in workforce migration to EU countries and their impact on economic and social development of the SR.

\section{References}

Bilan, Y. (2014), Migration aspirations on the outskirts of Europe: Social and economic dimensions, Transformations in Business and Economics, 13 (2B), pp. 606-614.

Czaika, M., de Haas, H. (2013), The Effectiveness of Immigration Policies, Population and Development Review, Published: Sep. 2013, Vol. 39, Issue 3, pp. 487-508, DOI: 10.1111/j.1728-4457.2013.00613.x. 
Čajka, P., Jaroszewicz, M., Strielkowski, W. (2014), Migration Incentives and Flows between Belarus, Moldova, Ukraine and the European Union: a Forecasting Model, Economics and Sociology, Vol. 7, No. 4, pp. 11-25.

Cuhlová, R. (2015), The effectiveness of migration policies for skilled foreigners: A case of the Czech Republic and Germany, 18th international colloquium on regional sciences, Brno: Masarykova univerzita, pp. 353-359, DOI: 10.5817/CZ.MUNI.P210-7861-2015-47.

Gress, M. (2014), Analysis of Ravenstein migration law, In: International relations 2014: Contemporary issues of World economics and politics, Smolenice, Slovakia pp: 206213.

Divinský, B. (2009), Migračné trendy v Slovenskej republike po vstupe krajín do EÚ (2004 2008), Bratislava: IOM Medzinárodná organizácia pre migráciu, p. 117.

EUROSTAT [cit. 11.4.2015], Available at: http://ec.europa.eu/eurostat/statisticsexplained/index.php/Glossary:Migration.

IOM [cit. 11.4.2015], Available at: www.iom.sk/pre-media/pojmy-o-migracii\#pojmymigracia.

Kumpikaite, V., Zickute, I. (2012), Synergy of Migration Theories: Theoretical Insights, Inzinerine Ekonomika - Engineering Economics, Vol. 23, Issue 4, pp. 387-394, DOI: 10.5755/j01.ee.23.4.1240.

Lipková, L. a kol. (2011), Medzinárodné hospodárske vzt’ahy, Bratislava: Sprint, p. 33.

Muchová, E. et al. (2011), Medzinárodná ekonómia - vybrané problem, Bratislava: Ekonóm, Ekonomická univerzita v Bratislave, Národohospodárska fakulta, p. 214.

Ravenstein, E. G. (1885), The Laws of Migration, Journal of the Statistical Society of London, Vol. 48, Issue 2 (1885), pp. 167-235.

Sadova, U. (2010), Migration risk in the context of social-economic transformation of Ukraine, Economics and Sociology, Vol. 3, No. 1a, pp. 89-96.

Stratégia Slovenskej Republiky pre Mládež na roky 2014 - 2020 [cit. 8.2.2016], Available at: https://www.minedu.sk/data/files/3889_strategia_pre_mladez.pdf.

Streimikiene, D., Bilan, Y., Jasinskas, E., Griksaite, R. (2016). Migration trends in Lithuania and other new EU member states, Transformations in Business and Economics, 15 (1), pp. 21-33.

Thomas, A. (2016), Degrees of Inclusion: Free Movement of Labour and the Unionization of Migrant Workers in the European Union, JCMS - Journal of Common Market Studies, Vol. 54, Issue 2, pp. 408-425.

Únia dala l'ud’om prácu, vonku robi 120-tisíc Slovákov (2014), [cit. 07.9.2016], Available at: http://profesia.pravda.sk/zamestnanie/clanok/316343-unia-dala-ludom-pracu-vonkurobi-120-tisic-slovakov/

Vojtovič, S. (2013), The Impact of Emigration on Unemployment in Slovakia, Inzinerine Ekonomika - Engineering Economics, Vol. 24, Issue 3, pp. 207-216.

STATISTICA. 